\title{
Management Pearls on the Treatment of Actinic Keratoses and Field Cancerization
}

\author{
Jaime Piquero-Casals (D) - Daniel Morgado-Carrasco • Yolanda Gilaberte • \\ Rubén Del Rio · Antonio Macaya-Pascual - Corinne Granger • \\ José Luis López-Estebaranz
}

Received: June 4, 2020 / Published online: July 17, 2020

(C) The Author(s) 2020

\section{ABSTRACT}

Field cancerization (FC) is a chronic disease involving multiple clinical and subclinical actinic keratoses (AK) on large photo-exposed surfaces with multifocal areas of dysplasia and

Digital Features To view digital features for this article go to https://doi.org/10.6084/m9.figshare.12600221.

J. Piquero-Casals $(\bowtie)$

Dermik Clinica Dermatológica Multidisciplinar, Barcelona, Spain

e-mail: j.piquero@dermik.es

D. Morgado-Carrasco

Dermatology Department, Hospital Clínic de

Barcelona, Universitat de Barcelona, Barcelona, Spain

Y. Gilaberte

Dermatology Department, Instituto de

Investigación Sanitaria (IIS) Aragón, Miguel Servet

University Hospital, Zaragoza, Spain

R. Del Rio

Dermatology Department, Hospital de L'Esperit

Sant, Santa Coloma de Gramenet, Barcelona, Spain

A. Macaya-Pascual

Dermatology Department, Hospital Universitari

Bellvitge, Barcelona, Spain

C. Granger

Innovation and Development, ISDIN, Barcelona, Spain

J. L. López-Estebaranz

Dermatology Department, Hospital Universitario

Fundación Alcorcón, Madrid, Spain precancerous changes. Patients and treatment must be properly monitored and managed to avoid aggravation and progression of the disease. Management of actinic keratoses includes lesion-directed treatments, such as cryotherapy and field-directed therapies. Field-directed therapies may have the potential to address subclinical damage, reduce $\mathrm{AK}$ recurrence rates and potentially reduce the risk of squamous cell carcinoma development. Multiple studies have demonstrated the efficacy of field-directed treatments, including 5-fluorouracil, photodynamic therapy, imiquimod, chemical exfoliation with trichloroacetic acid and diclofenac gel, for multiple AK and FC. The choice of therapy should be based on multiple factors, such as efficacy, tolerability, patient risk profile, costs and cosmetic results. Management of AK includes not only treatment but also prevention. Medical devices, such as sunscreens containing liposome-encapsulated DNA repair enzymes, can repair DNA damage associated with chronic UV radiation and reduce the number of new AK lesions. Here we provide therapeutic pearls and expert opinions on the treatment of AK and FC (as monotherapy or in combination) with the overall aim to achieve better, faster, and well-tolerated clinical responses.

Keywords: Actinic keratosis; Chemical peels; Cutaneous field cancerization; Photoaging; 
Photo-carcinogenesis; Photodynamic therapy; Photolyase; Sunscreens; 5-FU

\section{Key Summary Points}

The first step in the management of the patient with multiple actinic keratoses (AK) and field cancerization (FC) is rigorous sun protection.

Sunscreens should contain liposomal DNA-photolyase and high UVA and UVB protection filters to reduce subclinical FC.

Treatment of AK and FC can be lesiondirected or field-directed, and it can require the treatment of large surfaces.

The choice of therapy should be based on multiple factors such as efficacy, tolerability, patient risk profile, costs, and cosmetic results.

Nutricosmetics with Polypodium leucotomus can be an excellent option in patients who do outdoor activities, as an adjuvant to topical photoprotection in susceptible populations.

\section{INTRODUCTION}

Actinic keratoses (AK) are premalignant proliferations associated with chronic ultraviolet (UV) exposure, most frequently found on the face, ears, forearms, and hands. AK are associated with genomic alterations caused by the carcinogenic effect of sun exposure. The rate of progression of AK into squamous cell carcinoma (SCC) ranges from 0.025 to $16 \%$ per AK per year [1]. AK can present as solitary lesions, although patients generally develop multiple AK in one continuous area of actinically damaged skin, termed field cancerization (FC) [2] (Fig. 1). The concept of FC was first introduced by Slaughter et al. in 1953, when studying the presence of histologically abnormal tissue surrounding oral SCC [3]. FC was proposed to explain the

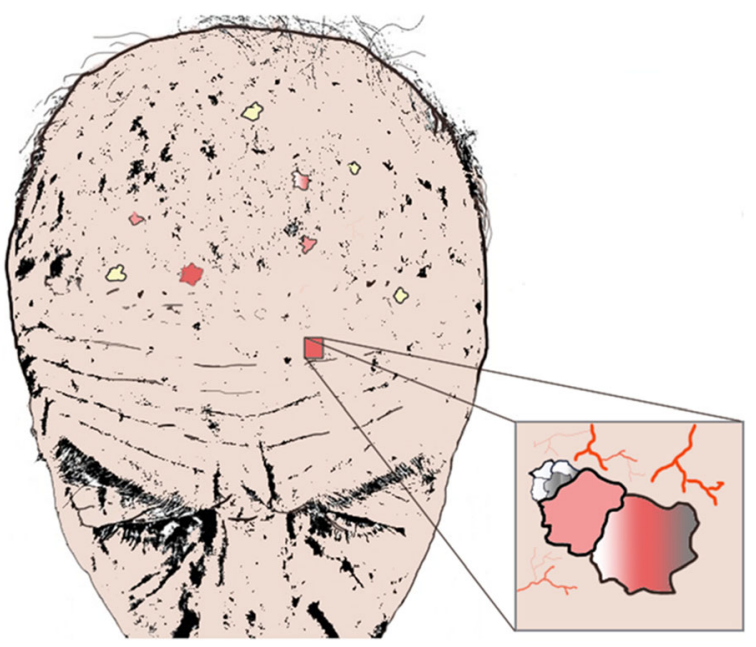

Fig. 1 Graphic representation of field cancerization on the scalp of an elderly patient, focusing on an area with dermatoscopic signs of actinic keratosis, white or silver scaly lesions, and telangiectasia

development of multiple primary tumors and locally recurrent cancer. Recent molecular findings support the carcinogenesis model in which the development of a field with genetically altered cells plays a central role [2].

Management of AK and FC can be challenging. Treatment of AK can be lesion-directed or field-directed, and it can require the treatment of large surfaces [4]. Field-directed therapies may have the potential to address subclinical damage, reduce $\mathrm{AK}$ recurrence rates, and potentially reduce the risk of SCC development [5].

Multiple studies have demonstrated the efficacy of treatments such as 5-fluorouracil, photodynamic therapy (PDT), and imiquimod for multiple AK [5-7]. Other therapies with less efficacy include ingenol mebutate, topical diclofenac gel, and piroxicam. The choice of therapy should be based on multiple factors, such as efficacy, tolerability, patient risk profile, costs, and cosmetic results [5, 8, 9] (Fig. 2).

Here we provide therapeutic pearls and expert opinions on the treatment of AK and FC (as monotherapy or in combination), with the overall aim to achieve better, faster and welltolerated clinical responses. Table 1 provides a summary of these pearls, which are described in detail in the text of this article. 




Fig. 2 Therapeutic algorithm for the treatment of actinic keratoses $(A K)$ and field cancerization. ${ }^{*}$ Also consider prescribing oral Polypodium leucotomus in patients who perform outdoor activities. ${ }^{\dagger} \mathrm{We}$ recommend prescribing field-directed therapies even in patients with a limited number of AK or no evident field cancerization. "When prescribing photodynamic therapy (PDT; conventional or daylight PDT), consider drug delivery with ablative

This article is based on previously conducted studies and does not contain any studies with human participants or animals performed by any of the authors. Patients gave written consent for the publication of photographs.

\section{THERAPEUTIC MANAGEMENT}

\section{Photoprotection}

Since UV radiation is a tumor initiator and tumor promoter of cutaneous cancer and because animal models have demonstrated reduced precursor lesions when UV exposure is interrupted, the first step in the management of the patient with multiple $\mathrm{AK}$ and $\mathrm{FC}$ is rigorous sun protection [10]. The sunscreens chosen should contain liposomal DNA-photolyase and high UVA and UVB protection filters [11]. The

flavoenzyme DNA-photolyase, which repairs DNA alterations in the presence of light $(300-500 \mathrm{~nm})$, is present in bacteria, plants and some non-placental mammals. The enzyme binds to cyclobutene pyrimidine dimers (CPD) and repairs them in a reaction triggered by electron transfer from the photo-excited flavin co-factor to the dimer, returning it to its monomeric form. Both in vitro and in vivo studies have supported the beneficial properties of photolyases in preventing and reversing photodamage [6]. Confocal reflectance microscopy, histopathology and immunohistochemistry studies have shown that a film-forming medical device containing photolyase and UV filters improves cutaneous FC clinically, reducing or improving subclinical FC associated with AK and nonmelanoma skin cancer (NMSC) [12]. The use of sunscreens containing DNA-photolyase can significantly reduce the number of 
Table 1 Pearls to enhance therapeutic response and patient adherence to treatments for actinic keratoses

\begin{tabular}{|c|c|c|c|}
\hline Treatment & Practical approach & $\begin{array}{l}\text { Pearls to enhance therapeutic } \\
\text { response }\end{array}$ & $\begin{array}{l}\text { Pearls to improve patient } \\
\text { adherence }\end{array}$ \\
\hline Photoprotection & $\begin{array}{l}\text { Use of sunscreens containing } \\
\text { DNA-photolyase }\end{array}$ & $\begin{array}{l}\text { Daytime use of a topical product } \\
\text { (medical device) with DNA } \\
\text { repair function paired with high } \\
\text { sun protection in fluid } \\
\text { presentation is an excellent } \\
\text { option for patients with scalp } \\
\text { lesions and alopecia }\end{array}$ & $\begin{array}{l}\text { Light texture of the product } \\
\text { allows perspiration and ensures } \\
\text { adhesion especially among men, } \\
\text { who may be more reluctant to } \\
\text { use daily sun creams }\end{array}$ \\
\hline 5-FU & $\begin{array}{l}\text { 5-FU is a cost-effective } \\
\text { treatment (more effective } \\
\text { and less costly) }\end{array}$ & $\begin{array}{l}\text { Use chemoprevention of } \\
\text { squamous cell carcinoma (SCC) } \\
\text { with } 5 \% 5 \text {-FU twice daily for } 1 \\
\text { month in high-risk patients }\end{array}$ & $\begin{array}{l}\text { Short treatment duration ( } 1 \\
\text { month) and fast improvement } \\
\text { of FC signs } \\
\text { If no available commercial } \\
\text { formulations of 5-FU, it can be } \\
\text { formulated in a Vaseline or } \\
\text { Beeler base }\end{array}$ \\
\hline PDT & $\begin{array}{l}\text { PDT is an extremely versatile } \\
\text { form of therapy }\end{array}$ & $\begin{array}{l}\text { Gauze abrasion, scrub soaps, } \\
\text { microdermabrasion or } \\
\text { sandpaper are mechanical } \\
\text { techniques to disrupt the } \\
\text { stratum corneum and enhance } \\
\text { skin penetration of the } \\
\text { photosensitizer for a uniform } \\
\text { and effective incubation } \\
\text { Ablative fractional laser and } \\
\text { microneedle can increase drug } \\
\text { delivery and can shorten } \\
\text { incubation time }\end{array}$ & $\begin{array}{l}\text { To reduce pain: } \\
\text { Daylight-PDT as a first-choice } \\
\text { procedure } \\
\text { Cold analgesia } \\
\text { Momentary interruption of PDT } \\
\text { Local nerve block } \\
\text { Single dose of NSAID prior to } \\
\text { PDT } \\
\text { Listening to music or talking } \\
\text { during the procedure }\end{array}$ \\
\hline Imiquimod & $\begin{array}{l}\text { Imiquimod is an effective form } \\
\text { of immunotherapy }\end{array}$ & $\begin{array}{l}\text { A } 12 \text {-day uninterrupted course of } \\
\text { imiquimod } 5 \% \text { instead of the } \\
\text { intermittent scheme of } 3 \text { nights } \\
\text { per week for } 4 \text { weeks can be an } \\
\text { effective protocol for managing } \\
\text { AK }\end{array}$ & $\begin{array}{l}\text { A } 12 \text {-day uninterrupted course of } \\
\text { imiquimod } 5 \% \text { may increase } \\
\text { adherence to therapy in clinical } \\
\text { practice }\end{array}$ \\
\hline Chemical peels & $\begin{array}{l}\text { Chemical peels can be cost- } \\
\text { effective when compared to } \\
\text { invasive procedures }\end{array}$ & $\begin{array}{l}30-45 \% \text { TCA is the most-used } \\
\text { peel for treatment of FC } \\
\text { Synergistic effect of glycolic acid } \\
\text { peels and 5-FU. Glycolic acid } \\
\text { can enhance penetration of } \\
\text { 5-FU, as it decreases corneocyte } \\
\text { cohesion }\end{array}$ & $\begin{array}{l}\text { Choosing the right chemical peel, } \\
\text { alone or in combination, is } \\
\text { crucial to achieve good tolerance } \\
\text { and predictability of results }\end{array}$ \\
\hline
\end{tabular}


Table 1 continued

\begin{tabular}{|c|c|c|c|}
\hline Treatment & Practical approach & $\begin{array}{l}\text { Pearls to enhance therapeutic } \\
\text { response }\end{array}$ & $\begin{array}{l}\text { Pearls to improve patient } \\
\text { adherence }\end{array}$ \\
\hline $\begin{array}{l}\text { Combined } \\
\text { treatments in } \\
\text { the clinic }\end{array}$ & $\begin{array}{l}\text { Several procedures or in-home- } \\
\text { treatments could be } \\
\text { combined to optimize FC } \\
\text { management approach }\end{array}$ & $\begin{array}{l}\text { At-home treatments could be } \\
\text { combined with in-clinic } \\
\text { procedures } \\
\text { Pretreatment with topical } 5 \% \\
\text { 5-FU twice daily for } 7 \text { days prior } \\
\text { to daylight-PDT can enhance } \\
\text { therapeutic responses } \\
\text { Chemical peels or fractionated } \\
\text { ablative lasers could be } \\
\text { combined with PDT to improve } \\
\text { results }\end{array}$ & $\begin{array}{l}\text { Use a repairing cream immediately } \\
\text { after the procedure as a "fire } \\
\text { extinguisher" (cooling effect) } \\
\text { Keep creams in a refrigerator or } \\
\text { immerse them in ice water } \\
\text { before the procedure. Products } \\
\text { containing triterpenes of Gotu } \\
\text { kola Centella asiatica associated } \\
\text { with rosehip oil are the best } \\
\text { options } \\
\text { Use of non-ablative energy } \\
\text { devices, such as intense pulsed } \\
\text { light or non-ablative Erbium- } \\
\text { Glass } 1550 \text { nm laser, in patients } \\
\text { in whom the recovery time due } \\
\text { to their occupation needs to be } \\
\text { minimal }\end{array}$ \\
\hline Oral therapy & $\begin{array}{l}\text { Nutricosmetics can be an } \\
\text { excellent alternative in } \\
\text { patients who do outdoor } \\
\text { activities, as an adjuvant to } \\
\text { topical photoprotection in } \\
\text { susceptible populations }\end{array}$ & $\begin{array}{l}\text { Nutricosmetics with Polypodium } \\
\text { leucotomus, Vitis vinifera and } \\
\text { green tea extract allows non- } \\
\text { photoadapters to respond to } \\
\text { therapeutic doses of daylight- } \\
\text { PDT giving better tolerance to } \\
\text { sun exposure and increasing the } \\
\text { minimum erythemal dose } \\
\text { Similar to PDT or topical therapy }\end{array}$ & $\begin{array}{l}\text { Preferable to use nutricosmetics } \\
\text { that can be prescribed once daily }\end{array}$ \\
\hline
\end{tabular}

$F C$ Field cancerization, 5-FU 5-fluorouracil, $P D T$ photodynamic therapy, SCC TCA trichloroacetic acid

AK [13] and can also be applied after treatments such as PDT [14].

\section{Pearl in Photoprotection}

The daytime use of a topical product in the medical device category which offers DNA repair function paired with high sun protection in a fluid presentation represents an excellent option for patients with scalp lesions and alopecia or with thinning hair. The light texture of the product allows perspiration and ensures adhesion, especially among men who may be more reluctant to use daily sun creams. The use of topical encapsulated photolyase is essential in the management of the patient susceptible to actinic damage or FC. It can be used as a monotherapy or as an adjunct treatment to PDT or cryotherapy [15].

It is also especially useful in patients who have already been treated preventively. Current evidence demonstrates its effectiveness and versatility of use [11]. 


\section{5-Fluorouracil}

A recently published clinical trial showed that topical 5\% fluorouracil (5-FU) was significantly more effective than imiquimod, methyl aminolevulinate-PDT (MAL-PDT) or ingenol mebutate at 12 months after the end of treatment for multiple AK lesions [16]. Similar findings were shown in a network meta-analysis [17]. Prophylactic treatment with topical 5-FU in high-risk patients can substantially reduce surgery for SCC for 1 year [18] and may decrease medical care costs [19].

\section{Pearls}

(1) Use chemoprevention of SCC with 5\% 5-FU twice daily for 1 month in high-risk patients [16]. This treatment can be performed twice or three times a year and may also improve the cosmetic appearance of photoaged skin.

(2) In countries with no available commercial formulations of 5-FU, it can be formulated in a Vaseline or Beeler base.

\section{Photodynamic Therapy}

Photodynamic therapy is based on the activation of a photosensitizing agent with subsequent release of reactive oxygen species and tissue destruction. A prodrug (aminolevulinic acid [ALA] or MAL [M-ALA]) is topically applied to the skin 1-3 $\mathrm{h}$ prior to visible-spectrum daylight, red light or blue light treatment [20]. PDT is an effective FC treatment and can be superior to lesion-directed destructive therapy [5]. The major side effect of conventional PDT is the pain experienced during therapy, especially when treating AKs located on the face and scalp, which may last for several hours after the procedure [21].

\section{Pearls for Better Results and Tolerability}

(1) Chemical products can be used for 5-7 days before PDT to reduce hyperkeratosis of the AK, such as $30-40 \%$ urea or $10 \%$ salicylic acid [22].
(2) Mechanical techniques can disrupt the stratum corneum and enhance skin penetration of the photosensitizer for a uniform and effective incubation. Be careful not to induce bleeding, which is inconvenient as it may displace the applied MAL cream and the effective light during PDT may be absorbed by hemoglobin [23].

(a) Gauze abrasion of the FC with 95\% alcohol is simple and inexpensive.

(b) Use scrub soaps prior to PDT or prescribe the use of a soap with exfoliating particles to remove residues, dead skin cells and dirt by physical drag or abrasive action, while surfactant components exert a powerful degreasing effect.

(c) Use of particle-free microdermabrasion. This allows an effective removal of the corneal layer in the clinic, curing more (superficial) keratotic lesions.

(d) Use of abrasive pads (sandpaper) for skin preparation [20].

(3) Enhance drug delivery.

(a) Ablative fractional laser (AFXL) to enhance drug delivery. This procedure creates microscopic vertical microchannels of ablated tissue, each surrounded by a thin layer of coagulated tissue and has proved to enhance photosensitizer uptake. The use of a fractional erbium:Yag $(2940 \mathrm{~nm})$ laser system or a fractionated $\mathrm{CO}_{2}(10,600 \mathrm{~nm})$ laser system with low fluence can shorten the incubation time of the photosensitizer to $1.5-2 \mathrm{~h}$, instead of $3-4 \mathrm{~h}$ [24] (Fig. 3).

(b) Microneedle-assisted PDT (MN-PDT). $\mathrm{MN}$ devices are micrometer-scale needles capable of puncturing the stratum corneum with minimal pain, shortening the incubation time for ALA and enhancing the efficacy of PDT [25]. MN-PDT can achieve an increase in mean lesion clearance; the 


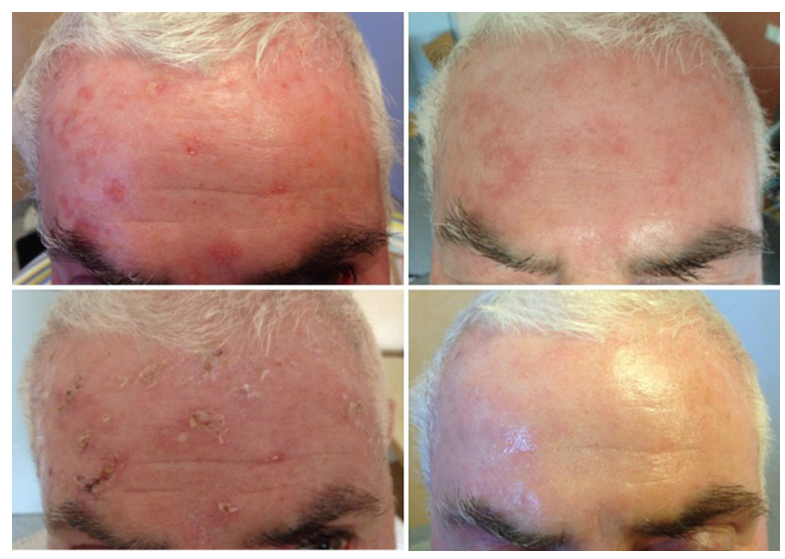

Fig. 3 Patient before and after treatment of multiple AK with ablative fractionated $\mathrm{CO}_{2} \quad 10,600 \mathrm{~nm}$ laser + PDT

photosensitizer is applied first then the MN-PDT is performed [26, 27].

(4) Enhance results for PDT in the extremities. The efficacy of PDT can be reduced when treating AK on the extremities. Pretreatment with topical 5\% 5-FU twice daily for 7 days prior to daylight PDT can enhance therapeutic responses [28].

(5) Reduce side effects in PDT.

(a) Daylight PDT as a first-choice procedure for AK. The photosensitizer (MAL or ALA) is applied for $30 \mathrm{~min}$ after curettage on the face or scalp, and the patient is instructed to expose the face or scalp to daylight for $2 \mathrm{~h}$. The incidence of complete response has been reported to be similar between daylight PDT and conventional PDT, but with lower risk of adverse events, and daylight PTD is better tolerated [29]. In order to avoid the discomfort and bleeding caused by curettage, the photosensitizer can be applied for $1 \mathrm{~h}$ before daylight exposure [30].

(b) Cold analgesia. The use of cold air blower machines, such as the Zimmer Cryo 6 system at level 5 (Zimmer MedizinSysteme GmbH, Neu-Ulm, Germany) decreases the superficial skin temperature and can considerably reduce pain during conventional PDT, without any loss of efficiency
[31]. After treatment, the use of cooling pads for at least $10 \mathrm{~min}$ can be very helpful. Cold pads can be applied at home in the $12 \mathrm{~h}$ immediately following PDT to relieve pain.

(c) Clobetasol propionate cream can be applied before and just after PDT to reduce erythema without decreasing efficacy [32].

(d) After the procedure, topical application of an epidermal recovery accelerator cream, such as gotu kola extract with rose hip oil (among others), can be recommended [33].

(e) Momentary interruption of PDT. Stopping PDT with a 3-min pause [21] or spraying cold water every $10 \mathrm{~s}$ during the procedure is highly effective to reduce pain [34].

(f) Local or regional anesthesia. Combination of supraorbital/supratrochlear and occipital nerve blocks with approximately $1 \mathrm{~mL}$ of subcutaneous injection of mepivacaine $3 \%$ may provide adequate pain relief during PDT on the forehead and scalp [35].

(g) Prescription of metamizole and acetaminophen 30-40 min prior to PDT may be a well-tolerated alternative for patients with multiple and erosive lesions [21].

(h) Play music and/or talk during the procedure. Listening to music or talking can help the patient to relax and feel more comfortable.

(i) As patients wear protective goggles during illumination, we recommend staying with the patient and asking about pain intensity on a scale between 0 and 10 ( 0 corresponding to no pain and 10 to severe pain). If the pain intensity is severe, between 7 and 10, the use of the practices/strategies described above is recommended.

(6) Acknowledging potential adverse events. Dermatologists must inform patients about possible side effects of PDT: itch, pain, erythema, edema, urticaria, exudation and crusting can be seen in the acute phase 
[20]. Severe adverse events are uncommon. Sterile pustules and purpura can present in the short term. Scarring, milia, hyper- or hypopigmentation and increased or reduced hair growth can be observed in the medium to long term. Patients should be encouraged to consult promptly; awareness may facilitate prevention and management.

\section{Imiquimod}

Imiquimod is an effective form of immunotherapy for the treatment of AK and FC [16]. It is an immune response modifier that activates immune cells via toll-like receptor 7 , initiating a cascade leading to the induction of cytokines, such as interferon alfa, interferon gamma, and interleukin 12 , which promote a $\mathrm{T}$ helper 1 (TH1) immune response [36].

\section{Pearl to Simplify Treatment Protocols With Imiquimod}

A 12-day uninterrupted course of imiquimod $5 \%$, instead of the intermittent scheme of 3 nights per week for 4 weeks, can be an effective protocol for managing $\mathrm{AK}$ and may increase adherence to therapy in clinical practice [37].

\section{Chemical Peels}

Chemical peels (CP) have been used to treat diverse aesthetic and medical skin conditions. Topical exfoliative agents, alone or in combination, are used to induce controlled cutaneous injury, ultimately resulting in epidermal turnover and collagen regeneration [38]. CP are widely used in cosmetics to improve the appearance of photoaged skin by reducing wrinkles and hyperpigmentation. Their role in treating and/or preventing photocarcinogenesis has yet to be determined [39]. However, guidelines from the British Association of Dermatologists suggest the inclusion of $\mathrm{CP}$ among valid field-directed treatment options for AK [40]. When used for the appropriate indication with the proper technique, CP can improve FC and photoaging, and can be cost-effective when compared to invasive procedures.

\section{Pearls for $C P$}

(1) Prepare the skin. 0\% topical glycolic acid or 30\% urea cream overnight can provide an exfoliating and keratolytic effect and may be beneficial for improving skin appearance, with better results and tolerance when the peel is performed.

(2) Choosing the right agent.

(a) When treating FC, the $\mathrm{CP}$ must be medium or deep to achieve results comparable with other procedures. The most commonly used $\mathrm{CP}$ is trichloroacetic acid (TCA) at a concentration between 30 and $45 \%$. It has a reasonable safety profile, with good tolerance and predictability of results. In some patients it can be used together with other agents [41].

(b) The combination of Jessner peeling with TCA has been used for the management of FC and photoaging. The original Jessner formula contains 14\% salicylic acid, 14\% resorcinol, and $14 \%$ lactic acid in 95\% ethanol alcohol. This alcoholic solution is applied with gauze, cotton or a brush and allowed to act for 3-5 min until the corneal layer is self-neutralized and partially denatured, with subsequent application of $15 \%$ or $30 \%$ TCA according to the patient's condition. A single session of Jessner's solution peel plus 35\% TCA can achieve results similar to those observed with 5-FU twice daily for 3 weeks.

(c) Deep phenol peels are one of the most effective CP methods for treating elderly patients with skin tumors. Phenol penetrates the skin and induces endothelial cell damage more rapidly than keratinocyte damage. It is likely that the apoptosis of endothelial cells in the dermis induces ischemic changes, eventually resulting in epidermal necrosis. Scarring and hyperpigmentation are more 
frequent than in TCA peelings, mainly in high-phototype patients. When absorbed systemically, phenol may cause serious side effects, such as cardiac toxicity and liver and kidney damage. These side effects highly correlate with the duration of the procedure and peeled surface area. Deep phenol peels should be reserved for selected patients and applied in small areas [42].

(3) Combining peels with other forms of therapy.

(a) Combining peels in different concentrations and cryotherapy. In cases of FC and hyperkeratotic AK, after using $30 \%$ TCA, higher concentrations of TCA can be applied with a small stick or combined with cryotherapy in thick hyperkeratotic lesions.

(b) TCA + 5-ALA PDT. Peels can also be combined with other treatments, such as 5-ALA-PDT, in an attempt to optimize outcomes and allow clinicians to tailor the treatment based on individual patient needs [43].

(c) 5-FU + glycolic acid. 0.5\% 5-FU cream applied after 4 weekly sessions of $20 \%$ glycolic acid peel can clear more than $90 \%$ of AK [44]. The combination of glycolic acid +5 -FU is also associated with a greater reduction in the number of telangiectasias, solar lentigines and rhytides than chemical peel alone, and is not associated with the erythema and pain seen with 5-FU monotherapy. Synergistic effects of glycolic acid +5 -FU are assumed to result from enhanced penetration of 5 -FU secondary to the decreased corneocyte cohesion produced by glycolic acid.

\section{Combined Treatments in the Clinic}

\section{Pearls}

(1) Use a repairing cream immediately after the procedure as a "fire extinguisher" for a cooling effect. We suggest keeping these creams in the refrigerator or, alternatively, to immersing them in ice water before the procedure. Products containing triterpenes of gotu kola with rosehip oil are the best options [33, 45].

(2) Use non-ablative energy devices, such as intense pulsed light or the non-ablative erbium:glass fiber $1550 \mathrm{~nm}$ laser system, as part of the treatment for photodamaged skin in patients for whom the recovery time due to their occupation needs to be very short or minimal and who cannot have a prolonged desquamation or appearance of dark scabs as occurs with ablative laser or CP.

\section{Oral Therapy}

\section{Pearls}

(1) Nutricosmetics with Polypodium leucotomus allow better tolerance to sun exposure and increase the minimum erythemal dose (MED) [46]. Nutricosmetics can be an excellent option in patients who do outdoor activities as an adjuvant to topical photoprotection in susceptible populations, as they restore the intracellular redox status and increase the MED, inducing photoadaptation and photo-immunoprotection. $P$. leucotomos extract decreases lipid peroxides and neutralizes superoxide anions and hydroxyl radicals after UV exposure. Its anti-inflammatory properties are attributed to reduced UVinduced cyclooxygenase- 2 expression, p53 suppressor gene mutations and formation of CPDs and inflammatory infiltrate in animal models [46].

(2) Oral retinoids in selected cases. Acitretin has the most robust evidence for chemoprophylaxis of NMSC and treatment and prophylaxis of $\mathrm{AK}$ in solid organ transplant recipients (Grade A recommendation) [47]. The evidence in the general population is low. Another option for younger patients is low-dose oral isotretinoin for the treatment of FC [48]. 
Table 2 Agents which may prevent the development of actinic keratoses and squamous cell carcinoma in high-risk patients

\begin{tabular}{|c|c|c|}
\hline Therapy & Agent & Dosage \\
\hline \multirow[t]{2}{*}{$\begin{array}{l}\text { Topical } \\
\text { therapy }\end{array}$} & $\begin{array}{l}\text { Sunscreens (especially those containing } \\
\text { DNA-photolyase) }\end{array}$ & Apply twice daily in photo-exposed areas \\
\hline & $5 \% 5-\mathrm{FU}$ & $\begin{array}{l}\text { Apply twice daily for } 30 \text { days. Two or three courses per year } \\
\text { may be indicated }\end{array}$ \\
\hline \multirow{3}{*}{$\begin{array}{l}\text { Oral } \\
\text { therapy }\end{array}$} & Retinoids & Retinol 25,000 IU/day \\
\hline & & Acitretin $25 \mathrm{mg} /$ daily \\
\hline & Nicotinamide & $500 \mathrm{mg}$ twice daily \\
\hline
\end{tabular}

(3) Oral nicotinamide for chemoprevention of AK and NMSC. Nicotinamide is a widely available over-the-counter drug. It is the active form of vitamin B3 (niacin) and a cofactor for adenosine triphosphate, which is essential for DNA repair. Oral nicotinamide (500 mg twice daily) was been found to be safe and effective in reducing the rates of AK and new NMSC in high-risk patients in a randomized clinical trial [49] (Table 2).

\section{Follow-Up and Monitoring}

Non-invasive techniques, such as photography, dermoscopy and reflectance confocal microscopy, and validated severity scores such as the Actinic Keratosis Area and Severity Index (AKASI), can be used to assess the severity of AK and may help in the follow-up and monitoring treatment responses [50, 51].

\section{CONCLUSIONS}

Management of AK and FC can be challenging. Prevention using oral or topical therapies should be considered, especially in high-risk patients. It is crucial to prescribe adequate photoprotection, such as sunscreens containing liposome-encapsulated DNA repair enzymes, and to perform field-directed therapies to properly treat FC. We recommend patient-tailored therapy. Multiple alternatives are available, including 5-FU, PDT, imiquimod and chemoexfoliation. Efficacy, tolerability, patient risk profile, costs and cosmetic results are factors to consider. Multiple approaches may achieve better outcomes and tolerability.

\section{ACKNOWLEDGEMENTS}

Funding. The journal's Rapid Service Fee was supported by ISDIN.

Medical Writing and/or Editorial Assistance. Editing assistance was provided by Jane Marshall (a freelance medical writer) and was funded by ISDIN.

Authorship. All named authors meet the International Committee of Medical Journal Editors (ICMJE) criteria for authorship for this article, take responsibility for the integrity of the work as a whole, and have given their approval for this version to be published.

Disclosures. Jaime Piquero-Casals, Yolanda Gilaberte, and José Luis López-Estebaranz are external advisors of ISDIN. Corinne Granger is employed by ISDIN. Daniel Morgado-Carrasco, Rubén Del Rio and Antonio Macaya-Pascual have nothing to disclose.

Compliance with Ethics Guidelines. This article is based on previously conducted studies and does not contain any studies with human participants or animals performed by any of the 
authors. Patients gave written consent for the publication of photographs.

Open Access. This article is licensed under a Creative Commons Attribution-NonCommercial 4.0 International License, which permits any non-commercial use, sharing, adaptation, distribution and reproduction in any medium or format, as long as you give appropriate credit to the original author(s) and the source, provide a link to the Creative Commons licence, and indicate if changes were made. The images or other third party material in this article are included in the article's Creative Commons licence, unless indicated otherwise in a credit line to the material. If material is not included in the article's Creative Commons licence and your intended use is not permitted by statutory regulation or exceeds the permitted use, you will need to obtain permission directly from the copyright holder. To view a copy of this licence, visit http://creativecommons.org/licenses/by$\mathrm{nc} / 4.0 /$.

Open Access. This article is licensed under a Creative Commons Attribution-NonCommercial 4.0 International License, which permits any non-commercial use, sharing, adaptation, distribution and reproduction in any medium or format, as long as you give appropriate credit to the original author(s) and the source, provide a link to the Creative Commons licence, and indicate if changes were made. The images or other third party material in this article are included in the article's Creative Commons licence, unless indicated otherwise in a credit line to the material. If material is not included in the article's Creative Commons licence and your intended use is not permitted by statutory regulation or exceeds the permitted use, you will need to obtain permission directly from the copyright holder. To view a copy of this licence, visit http:// creativecommons.org/licenses/by-nc/4.0/.

\section{REFERENCES}

1. Glogau RG. The risk of progression to invasive disease. J Am Acad Dermatol. 2000;42(1 Pt 2):23-4.
2. Fernandez Figueras MT. From actinic keratosis to squamous cell carcinoma: pathophysiology revisited. J Eur Acad Dermatol Venereol. 2017;31(Suppl 2):5-7.

3. Slaughter DP, Southwick HW, Smejkal W. Field cancerization in oral stratified squamous epithelium; Clinical implications of multicentric origin. Cancer. 1953;6(5):963-8.

4. Willenbrink TJ, Ruiz ES, Cornejo C, Schmults CD, Arron S, Jambusaria-Pahlajani A. Field cancerization: definition, epidemiology, risk factors, and outcomes. J Am Acad Dermatol. 2020;S01909622(20)30791-X. https://doi.org/10.1016/j.jaad. 2020.03.126.

5. Jetter N, Chandan N, Wang S, Tsoukas M. Field cancerization therapies for management of actinic keratosis: a narrative review. Am J Clin Dermatol. 2018;19:543-57.

6. Longo I, Serra-Guillén C. Quality of life, behaviour and attitudes towards actinic keratosis in Spain: the PIQA study. Actas Dermosifiliogr. 2018;109:331-9.

7. Kopera D. Earliest stage treatment of actinic keratosis with imiquimod $3.75 \%$ cream: two case reports-Perspective for non melanoma skin cancer prevention. Dermatol Ther. 2020;e13517. https:// doi.org/10.1111/dth.13517.

8. Navarrete-Dechent C, Marghoob AA, Marchetti MA. Contemporary management of actinic keratosis. J Dermatol Treat. 2019;1-3. https://doi.org/10. $1080 / 09546634.2019 .1682504$.

9. Philipp-Dormston WG, Battistella M, Boussemart L, Di Stefani A, Broganelli P, Thoms KM. Patient-centered management of actinic keratosis. Results of a multi-center clinical consensus analyzing non-melanoma skin cancer patient profiles and field-treatment strategies. J Dermatolog Treat. 2019;1-7. https://doi.org/10.1080/09546634.2019.1679335.

10. Christensen SR. Recent advances in field cancerization and management of multiple cutaneous squamous cell carcinomas. F1000Research. 2018;7: F1000. https://doi.org/10.12688/f1000research. 12837.1.

11. Puig S, Granger C, Garre A, et al. Review of clinical evidence over 10 years on prevention and treatment of a film-forming medical device containing photolyase in the management of field cancerization in actinic keratosis. Dermatol Ther (Heidelb). 2019;9:259-70.

12. Puig-Butillé JA, Malvehy J, Potrony M, et al. Role of CPI-17 in restoring skin homoeostasis in cutaneous field of cancerization: effects of topical application of a film-forming medical device containing 
photolyase and UV filters. Exp Dermatol. 2013;22: 494-6.

13. Navarrete-Dechent C, Molgó M. The use of a sunscreen containing DNA-photolyase in the treatment of patients with field cancerization and multiple actinic keratoses: a case-series. Dermatol Online J. 2017;23(1):13030/qt5zc6085s.

14. Eibenschutz L, Silipo V, De Simone P, et al. A 9-month, randomized, assessor-blinded, parallelgroup study to evaluate clinical effects of filmforming medical devices containing photolyase and sun filters in the treatment of field cancerization compared with sunscreen in patients after successful photodynamic therapy for actinic keratosis. Br J Dermatol. 2016;175(6):1391-3.

15. Vaño-Galván S, Jiménez N, Grillo E, Ballester A. An observational study on the effectiveness and safety of the combination of a topical product containing photolyase and cryotherapy in patients with actinic keratoses in clinical practice. Piel. 2016;31(8):532-6 [in Spanish].

16. Jansen MHE, Kessels JPHM, Nelemans PJ, et al. Randomized trial of four treatment approaches for actinic keratosis. N Engl J Med. 2019;380:935-46.

17. Gupta AK, Paquet M. Network meta-analysis of the outcome 'participant complete clearance' in nonimmunosuppressed participants of eight interventions for actinic keratosis: a follow-up on a Cochrane review. Br J Dermatol. 2013;169:250-9.

18. Weinstock MA, Thwin SS, Siegel JA, et al. Chemoprevention of basal and squamous cell carcinoma with a single course of fluorouracil, 5\%, cream: a randomized clinical trial. JAMA Dermatol. 2018;154:167-74.

19. Yoon J, Phibbs CS, Chow A, et al. Impact of topical fluorouracil cream on costs of treating keratinocyte carcinoma (nonmelanoma skin cancer) and actinic keratosis. J Am Acad Dermatol. 2018;79:501-507. e2.

20. Morton CA, Szeimies R-M, Sidoroff A, Braathen LR. European guidelines for topical photodynamic therapy part 1: treatment delivery and current indications-actinic keratoses, Bowen's disease, basal cell carcinoma. J Eur Acad Dermatol Venereol. 2013;27:536-44.

21. Gholam P, Denk K, Sehr T, et al. Factors influencing pain intensity during topical photodynamic therapy of complete cosmetic units for actinic keratoses. J Am Acad Dermatol. 2010;63:213-8.

22. Gholam P, Fink C, Bosselmann I, Enk AH. Retrospective analysis evaluating the effect of a keratolytic and physical pretreatment with salicylic acid, urea and curettage on the efficacy and safety of photodynamic therapy of actinic keratoses with methylaminolaevulinate. J Eur Acad Dermatol Venereol. 2016;30:619-23.

23. Anderson RR, Parrish JA. The optics of human skin. J Invest Dermatol. 1981;77:13-9.

24. Wolf P. Ablative fractional laser-fortified daylight photodynamic therapy may be the patient's preferred choice for the treatment of field cancerization. Br J Dermatol. 2019;180:697-8.

25. Lev-Tov H, Larsen L, Zackria R, et al. Microneedleassisted incubation during aminolaevulinic acid photodynamic therapy of actinic keratoses: a randomized controlled evaluator-blind trial. Br J Dermatol. 2017;176:543-5.

26. Petukhova TA, Hassoun LA, Foolad N, et al. Effect of expedited microneedle-assisted photodynamic therapy for field treatment of actinic keratoses: a randomized clinical trial. JAMA Dermatol. 2017;153:637-43.

27. Steeb T, Wessely A, Leiter U, French LE, Berking C, Heppt MV. The more the better? An appraisal of combination therapies for actinic keratosis. J Eur Acad Dermatol Venereol. 2020;34(4):727-32.

28. Nissen CV, Heerfordt IM, Wiegell SR, et al. Pretreatment with 5-fluorouracil cream enhances the efficacy of daylight-mediated photodynamic therapy for actinic keratosis. Acta Derm Venereol. 2017;97:617-21.

29. Mei X, Wang L, Zhang R, Zhong S. Daylight versus conventional photodynamic therapy for the treatment of actinic keratosis: a meta-analysis of randomized controlled trials. Photodiagnosis Photodyn Ther. 2019;25:23-8.

30. Heerfordt IM, Wulf HC. Daylight photodynamic therapy of actinic keratosis without curettage is as effective as with curettage: a randomized clinical trial. J Eur Acad Dermatol Venereol. 2019;33(11):2058-61.

31. Pagliaro J, Elliott T, Bulsara M, King C, Vinciullo C. Cold air analgesia in photodynamic therapy of basal cell carcinomas and Bowen's disease: an effective addition to treatment: a pilot study. Dermatol Surg. 2004;30(1):63-6.

32. Wiegell SR, Petersen B, Wulf HC. Topical corticosteroid reduces inflammation without compromising the efficacy of photodynamic therapy for actinic keratoses: a randomized clinical trial. $\mathrm{Br} \mathrm{J}$ Dermatol. 2014;171(6):1487-92.

33. Bylka W, Znajdek-Awiżeń P, Studzińska-Sroka E, et al. Centella asiatica in dermatology: an overview. Phytother Res. 2014;28:1117-24. 
34. Wiegell SR, Haedersdal M, Wulf HC. Cold water and pauses in illumination reduces pain during photodynamic therapy: a randomized clinical study. Acta Derm Venereol. 2009;89:145-9.

35. Halldin CB, Paoli J, Sandberg C, et al. Nerve blocks enable adequate pain relief during topical photodynamic therapy of field cancerization on the forehead and scalp. Br J Dermatol. 2009;160: 795-800.

36. Dika E, Fanti PA, Lambertini M, et al. Cutaneous squamous cell carcinoma progression during imiquimod treatment. J Am Acad Dermatol. 2018;79(1):e11-e12.

37. Serra-Guillén C, Nagore E, Llombart B, et al. A 12-day course of imiquimod 5\% for the treatment of actinic keratosis: effectiveness and local reactions. Actas Dermosifiliogr. 2018;109:248-53.

38. Sidiropoulou P, Gregoriou S, Rigopoulos D, Kontochristopoulos G. Chemical peels in skin cancer: a review. J Clin Aesthet Dermatol. 2020;13:53-7.

39. Fischer TC, Perosino E, Poli F, et al. Chemical peels in aesthetic dermatology: an update 2009. J Eur Acad Dermatol Venereol. 2010;24:281-92.

40. de Berker D, McGregor JM, Mohd Mustapa MF, et al. British Association of Dermatologists' guidelines for the care of patients with actinic keratosis 2017. Br J Dermatol. 2017;176:20-43.

41. López Martín-Prieto S, Sánchez Conejo-Mir J. Peeling químico con ácido tricloroacético. Un peeling clásico de máxima actualidad. Actas Dermosifiliogr. 2001;92:537-47.

42. Kaminaka C, Yamamoto Y, Yonei N, et al. Phenol peels as a novel therapeutic approach for actinic keratosis and Bowen disease: prospective pilot trial with assessment of clinical, histologic, and immunohistochemical correlations. J Am Acad Dermatol. 2009;60:615-25.

43. Holzer G, Pinkowicz A, Radakovic S, et al. Randomized controlled trial comparing 35\% trichloroacetic acid peel and 5-aminolaevulinic acid photodynamic therapy for treating multiple actinic keratosis. Br J Dermatol. 2017;176:1155-61.

44. Goldberg DJ. Case-based experience in the use of 5 -fluorouracil cream $0.5 \%$ as monotherapy and in conjunction with glycolic acid peels for the treatment of actinic keratosis. J Cosmet Laser Ther. 2010;12:42-6.

45. Ayati Z, Amiri MS, Ramezani M, Delshad E, Sahebkar A, Emami SA. Phytochemistry, traditional uses and pharmacological profile of rose hip: a review. Curr Pharm Des. 2018;24(35):4101-24.

46. Granger C, Aladren S, Delgado J, et al. Prospective evaluation of the efficacy of a food supplement in increasing photoprotection and improving selective markers related to skin photo-ageing. Dermatol Ther (Heidelb). 2020;10:163-78.

47. Herold M, Good AJ, Nielson CB, Longo MI. Use of topical and systemic retinoids in solid organ transplant recipients: update and review of the current literature. Dermatol Surg. 2019;45(12):1442-9.

48. Bettoli V, Zauli S, Virgili A. Retinoids in the chemoprevention of non-melanoma skin cancers: why, when and how. J Dermatol Treat. 2013;24: $235-7$.

49. Chen AC, Martin AJ, Choy B, et al. A phase 3 randomized trial of nicotinamide for skin-cancer chemoprevention. N Engl J Med. 2015;373: 1618-26.

50. Schmitz L, Gambichler T, Gupta G, et al. Actinic keratosis area and severity index (AKASI) is associated with the incidence of squamous cell carcinoma. J Eur Acad Dermatol Venereol. 2018;32: 752-6.

51. López Estebaranz JL, Pampín Franco A, Gamo Villegas R, Floristán U. Monitoring ingenol mebutate gel treatment of actinic keratoses by reflectance confocal microscopy. Acta Derm Venereol. 2017;97: 646-8. 